вышесказанным, а также в связи с существованием достаточно разветвленной системы нормативных правовых актов, преимущественно, ведомственных подзаконных актов, на наш взгляд, административный процесс следует изучать как отдельную учебную дисциплину в высших юридических учебных заведениях для углубленного изучения студентами порядка осуществления государственного контроля.

$* * *$

1. Салищева Н. Г. Административный процесс в СССР. М., 1964. 158 с.

2. Котюргин, С. И. Административный процесс. Автореферат дис. на соискание ученой степени кандидата юридических наук. М., 1968. 15 с.

3. Шахрай С.М. Административное право России: учебник для вузов. М., 2001. 576 с.

4. Старилов Ю. Н. Административный процесс в трудах профессора В. Д. Сорокина: «управленческая концепция» и ее значение для науки административного права // Административное право и процесс. 2015. № 1. С. 19.

5. Сорокин В. Д. Правовое регулирование: Предмет, метод, процесс (макроуровень). СПб., 2003. 661 c.

6. Стахов А. И. Интегративный подход к пониманию административного процесса в России // Административное право и процесс. 2015. № 2. С. 18.

7. Заика М.Л., Шарипова Э.А. Правовые основы служебного поведения государственных гражданских служащих и муниципальных служащих в субъектах Российской Федерации // Евразийский юридический журнал. 2020. № 11 (150). С. 119.

8. Шарипов В.Г., Шарипова Э.А. К вопросу о правовых основах осуществления государственных и муниципальных закупок в Российской Федерации // Экономические исследования и разработки. 2020. № 3. C. 12.

\title{
Гусейнова Р.A.
}

\section{Товарищество собственников жилья как форма управления многоквартирным домом}

Дальневосточный федеральный университет (Россия, Владивосток)

doi: 10.18411/lj-04-2021-224

Научный руководитель Погодина Т.И.

\section{Аннотация}

В статье раскрывается такое понятие как товарищество собственников жилья, дается краткая характеристика ТСЖ, перечисляются признаки ТСЖ, названы плюсы и минусы ТСЖ как формы управления многоквартирным домом.

Ключевые слова: товарищество собственников жилья, многоквартирный дом, признаки ТСЖ, создание ТСЖ, реорганизация и ликвидация ТСЖ.

\section{Abstract}

The article reveals such a concept as a homeowners 'partnership, gives a brief description of a homeowners' partnership, lists the signs of a homeowners 'partnership, identifies the pros and cons of a homeowners' partnership as a form of management of an apartment building.

Key words: homeowners' association, apartment building, signs of homeowners association, homeowners' association creation, reorganization and liquidation of homeowners' association.

Данная статья посвящена товариществам собственников жилья (далее - ТСЖ). Изучение этой темы не теряет своей актуальности с момента российской жилищноправовой реформы с начала 90-х годов прошлого столетия, которая положила начало как приватизации жилищного фонда, так и переходу функций управления многоквартирными домами (далее - МКД) из полномочий государства в руки рядовых 
граждан. Даже после вступления в силу 1 марта 2005 г. Жилищного Кодекса РФ (далее - ЖК РФ) институт ТСЖ не раз реформировался, что не снизило сложности его применения обычным гражданином.

Сущность ТСЖ заключается в том, что, будучи объединением домовладельцев, данная организация является одной из форм управления МКД.

ТСЖ представляет собой некоммерческое юридическое лицо. Прежде чем дать понятие «ТСЖ», поговорим о порядке создания, реорганизации и ликвидации ТСЖ.

Созданию и регистрации ТСЖ посвящена ст. 136 ЖК РФ. Указанной нормой императивно установлен запрет на создание двух и более ТСЖ для управления одним многоквартирным домом. Однако одно ТСЖ при этом по смыслу данного законоположения может быть создано на базе двух или нескольких МКД.

Выбор ТСЖ как формы управления многоквартирным домом также происходит только путем проведения общего собрания собственников жилья. Решение о создании ТСЖ считается принятым, если за него проголосовали собственники помещений в соответствующем МКД, обладающие более чем 50 \% голосов от общего числа голосов собственников помещений в таком доме. Из данного положения вполне объективно вытекают следующие выводы:

1) членами товарищества не обязательно будут все собственники жилых помещений в многоквартирном доме;

2) количество голосов может и не совпадать с числом собственников жилых помещений: так, одно жилое помещение может принадлежать на праве собственности нескольким лицам;

3) решения, принимаемые ТСЖ, на практике принимают меньшинство собственников жилья в МКД.

Необходимо отметить тот факт, что решение о создании ТСЖ будет тогда законным, когда в нем будут содержаться подписи всех собственников, которые голосовали за принятие такого решения. На этом же собрании необходимо и решить вопрос о принятии устава ТСЖ. Данный вопрос, впрочем, решается также как и первый, однако при составлении проекта устава ТСЖ следует обратить внимание на его содержание: полный и императивный перечень вопросов, которые должны быть предусмотрены уставом ТСЖ, содержится в ч. 2 ст. 135 ЖК РФ.

Очередным обязательным правилом является указание на то, что число членов ТСЖ, создавших товарищество, должно превышать 50 \% голосов от общего числа голосов собственников всех помещений в МКД. Данный «минимум» членов ТСЖ необходимо поддерживать и после создания ТСЖ под страхом ликвидации. Т. е. в случае, когда в результате выхода (по самым различным причинам) членов ТСЖ из товарищества их число окажется менее половины всех собственников в данном МКД, то товарищество обязано ликвидироваться в силу прямого указания ч. 2 ст. 141 ЖК РФ.

После принятия устава и достижения согласия о создании ТСЖ необходимо зарегистрировать ТСЖ как юридическое лицо по правилам, предусмотренным ЖК РФ и Федеральным законом от $08.08 .2001 \quad \mathrm{~N}$ 129-Ф3 (ред. от 31.12.2017) "О государственной регистрации юридических лиц и индивидуальных предпринимателей". Для этого необходимо обратиться в соответствующий налоговый орган по месту нахождения постоянно действующего исполнительного органа ТСЖ. В данный орган необходимо представить следующий перечень документов:

1) заявление о государственной регистрации ТСЖ согласно форме, подписанное уполномоченным лицом (это может быть лицо, уполномоченное на общем собрании или уже выбранный председатель ТСЖ);

2) устав ТСЖ (в двух экземплярах); 
3) протокол общего собрания собственников помещений в МКД, на котором приняты решения о создании товарищества и об утверждении его устава;

4) сведения о лицах, проголосовавших на общем собрании собственников помещений в МКД за создание ТСЖ, о принадлежащих этим лицам долях в праве общей собственности на общее имущество в МКД;

5) документ об уплате госпошлины. За государственную регистрацию ТСЖ уплачивается государственная пошлина (пп. 1 п. 1 ст. 333.33 Налогового Кодекса РФ) в размере 4000 рублей;

6) нотариальная доверенность (если с документами обращается представитель).

В результате государственной регистрации ТСЖ выдается документ, подтверждающий факт его регистрации - это свидетельство о государственной регистрации юридического лица.

ТСЖ прекращает свою деятельность путем реорганизации. Общее собрание членов товарищества вправе произвести слияние с другим аналогичным товариществом либо присоединение к нему или провести преобразование товарищества. Реорганизация в форме разделения и выделения возможна только в случае, если ТСЖ было создано в двух или более МКД. При этом Крашенинников П.В. отмечает, что «возможность преобразования ТСЖ в жилищный или жилищностроительный кооператив противоречит и здравому смыслу, и законодательству». Это действительно парадоксально, ведь ЖК и ЖСК создаются с целью обеспечения жильем своих членов, тогда как члены ТСЖ и так уже являются собственниками своих жилых помещений.

Проанализировав порядок создания, государственной регистрации, реорганизации и ликвидации ТСЖ, необходимо дать понятие «ТСЖ». Жилищное законодательство дает нам понятие «ТСЖ» в ч. 1 ст. 135 ЖК РФ. Однако данная дефинитивная норма представляется весьма перегруженной, из-за чего есть опасения, что «рядовой» гражданин, открыв Кодекс, не сможет правильно определить, в чем же заключается сущность ТСЖ.

Ограничимся только перечислением тех признаков, которые вытекают из законодательной дефиниции «ТСЖ». Во-первых, ТСЖ является одним из видов товарищества собственников недвижимости (далее-ТСН), соответственно ему присуще все то регулирование, которое содержится в ГК РФ о ТСН. Во-вторых, обозначены цели деятельности ТСЖ, которые выражены более широким образом применительно к целям управления МКД (ст. 161 ЖК РФ). Так, формулировка ст. 135 ЖК РФ позволяет товариществу в установленных случаях распоряжаться общим имуществом в МКД, а также заниматься «приращением» такого имущества. Закреплена также возможность предоставления коммунальных услуг собственникам жилья в МКД, что в своей сущности подменяет деятельность ресурсоснабжающих организаций. Таким образом, исходя из анализа законодательного определения, следует сделать вывод, что оно сформулировано лишь по целевому признаку и не учитывает иных признаков ТСЖ. Поэтому постараемся дать свое определение «ТСЖ», предварительно раскрыв его признаки.

Признаки ТСЖ можно условно поделить на две группы: признаки свойственные ТСЖ как юридическому лицу и сущностные признаки ТСЖ. Такое разделение обусловлено тем, что у ТСЖ как у некоммерческой организации «цели создания и деятельности большинства из них находятся за пределами правовой регламентации и в определенных случаях могут быть достигнуты без признания соответствующих образований субъектами гражданского права».

Признаки ТСЖ как юридического лица, вытекают из доктрины гражданского права и собственно ст. 48 ГК РФ: 
1. ТСЖ обладает организационным единством. Этот признак заключается в том, что у ТСЖ имеются определенные внутренние органы, которые находятся в системной связи друг с другом. Организационное единство юридического лица отражается в его учредительном документе - уставе;

2. ТСЖ обладает имущественной обособленностью. Данный признак означает, что имущество ТСЖ отделено от имущества других лиц, в частности его учредителей, т.е. членов ТСЖ. Имущественная обособленность ТСЖ отражается в самостоятельном бухгалтерском балансе и смете, а также дополнительно можно выявить этот признак и в том, что ТСЖ может иметь расчетный и иные счета в банке. Помимо этого, согласно ст. 151 ЖК РФ закрепляются имущественные права ТСЖ на движимые и недвижимые вещи, а также определяются пути получения такого имущества;

3. ТСЖ обладает самостоятельной имущественной ответственностью. Этот признак раскрывается в ч. 6 ст. 135 ЖК РФ, согласно которой ТСЖ отвечает по своим обязательствам всем принадлежащим ему имуществом. ТСЖ не отвечает по обязательствам членов товарищества, а члены ТСЖ не отвечают по обязательствам товарищества;

4. ТСЖ обладает способностью выступать в гражданском обороте от собственного имени. Этот признак выражается в ч. 2 ст. 135 ЖК РФ: устав ТСЖ должен содержать сведения о его наименовании, включающем слова "товарищество собственников жилья". Но это не главное его выражение. ТСЖ является некоммерческой организацией, соответственно получение прибыли в качестве своей основной цели не имеет, однако согласно ст. 152 ЖК РФ для достижения целей, предусмотренных уставом, ТСЖ вправе заниматься хозяйственной деятельностью (например, сдача в аренду или внаем части общего имущества МКД и пр.). Доход, полученный в результате такой деятельности, распределяется только на цели, которые выбрало общее собрание членов ТСЖ.

Правоспособность ТСЖ - специальная, поэтому учредителям важно правильно определить цели еще при создании ТСЖ.

Переходя к сущностным признакам, следует назвать тот факт, что ТСЖ - это, во-первых, объединение собственников помещений, т. е. буквально соседей (этот признак раскрывает социальную функцию товарищества). Во-вторых, ТСЖ это, собственно, одна из форм управления МКД. В-третьих, ТСЖ создается для управления (владение, пользование и в установленных случаях распоряжение) общим имуществом.

На основании вышеназванных признаков ТСЖ следует понимать как объединение собственников жилых помещений в МКД, зарегистрированное в установленном порядке в качестве юридического лица, созданное в целях управления МКД и общим имуществом собственников в МКД, а также для создания, содержания, сохранения и приращения указанного имущества.

Членом ТСЖ можно стать в двух случаях: подача заявления о вступлении в ТСЖ, которое нельзя отклонить, а также с самого начала создания ТСЖ путем голосования «за» его создание. При вступлении в члены ТСЖ кандидат обязан предоставить достоверную информацию о себе, а в случае необходимости обновлять ее. В свою очередь ТСЖ ведет реестр своих членов, в котором содержаться все необходимые сведения о членах ТСЖ.

Членство в ТСЖ прекращается также по двум основаниям. Во-первых, в случае подачи заявление о выходе из членов ТСЖ. Во-вторых, с момента отпадения титула, т. е. прекращения права собственности на жилое помещение в МКД. 
Лица, хоть и не являющиеся членами ТСЖ, все-таки имеют определенные права по отношению к ТСЖ. Данное положение вполне логично, иначе отсутствие какихлибо правомочий у данных лиц в этом случае означало бы неправомерное ограничение прав собственников жилых помещений в МКД. Так, названные лица имею право:

1. Получать от органов управления товарищества информацию о деятельности товарищества;

2. Обжаловать в судебном порядке решения органов управления товарищества;

3. Предъявлять требования к товариществу относительно качества оказываемых услуг и (или) выполняемых работ;

4. Ознакомиться с внутренними документами товарищества.

ТСЖ как форма управления МКД в результате всего вышеназванного показывает себя как достаточно эффективная модель управления общим имуществом в МКД. Однако, несмотря на достаточно большое количество зарегистрированных ТСЖ (по данным на сайте государственной корпорации «Фонд содействия реформированию жилищно-коммунального хозяйства») львиной долей домов до сих пор управляют «управляйки». Причиной этому является проблема не столько правовая, сколько социальная - граждане просто не готовы взять на себя обязанности по управлению МКД, не готовы скооперироваться вместе с соседями для достижения общего блага. Такая «леность» так или иначе является основанием для прихода управляющей организации, уровень доверия к которой у тех же граждан гораздо ниже, но граждане все-равно остаются бездействовать.

Таким образом, несмотря на приближенность ТСЖ к гражданам, эффективность и самостоятельность управления МКД при этой форме, ТСЖ все же остается неизвестной гражданину «экзотикой». Поэтому необходимо воспитывать грамотного собственника МКД, который будет осведомлен о правовых основах жилищного права. Прежде всего такая обязанность лежит на публичных институциях: в школах должны прививать правовые знания в названной сфере, а органы государственной власти и местного самоуправления должны проводить информационно-просветительскую работу с населением.

$$
* * *
$$

1. Гражданский кодекс Российской Федерации (часть первая): федеральный закон от $30.11 .1994 \mathrm{~N}$ 51-Ф3 // "Российская газета", N 238-239, 08.12.1994 (ред. от 29.12.2017).

2. Жилищный кодекс Российской Федерации: федеральный закон от 29.12.2004 N 188-Ф3 // "Российская газета", N 1, 12.01.2005 (ред. от 31.12.2017).

3. Налоговый кодекс Российской Федерации (часть вторая): федеральный закон от 05.08.2000 N 117Ф3 // "Парламентская газета", N 151-152, 10.08 .2000 (ред. от 29.12.2017).

4. О государственной регистрации юридических лиц и индивидуальных предпринимателей: федеральный закон от 08.08.2001 N 129-Ф3 // "Российская газета", N 153-154, 10.08.2001 (ред. от 31.12.2017).

5. Об утверждении форм и требований к оформлению документов, представляемых в регистрирующий орган при государственной регистрации юридических лиц, индивидуальных предпринимателей и крестьянских (фермерских) хозяйств: приказ ФНС России от 25.01.2012 N MMB-7-6/25@// "Бюллетень нормативных актов федеральных органов исполнительной власти", N 44, 29.10.2012 (ред. от 25.05.2016).

6. Крашенинников, П.В. Жилищное право. 9-е изд., перераб. и доп. М.: Статут, 2016. 384 с.

7. Кузьмак, Р. Легитимное создание ТСЖ в нарушение закона: пути выхода / Р. Кузьмак // Жилищное право. 2014. N 7. С. 45 - 52.

8. Перепелкина, Н.В. Товарищество собственников жилья: создание и деятельность / Н.В. Перепелкина // Законы России: опыт, анализ, практика. 2012. N 7. С. 92 - 99.

9. Сойфер, Т.В. Некоммерческие организации: некоторые проблемы гражданско-правового статуса / Т.В. Сойфер // Законы России: опыт, анализ, практика. 2010. N 2. С. 3 - 13.

10. Фролова, О.Е. Управляйте домом правильно: что нужно знать собственнику жилья / О.Е. Фролова, С.С. Сохранов, С.А. Яременко и др. М.: Редакция "Российской газеты", 2017. Вып. 20. 176 с. 